\title{
Study on Catalytic Oxidation, Flocculation and Sedimentation of Acidizing and Fracturing Wastewater
}

\author{
T. Yu*(**)***, F. Wang*(**), H. Hu*(**), C. Qu*(**)† and Le Zhang*(**) \\ *College of Chemistry and Chemical Engineering, Xi' an Shiyou University, Xi'an 710065, P. R. China \\ **Shaanxi Key Laboratory of Environmental Pollution Control Technology and Reservoir Protection of Oil Field, Xi' an \\ Shiyou University, Xi'an 710065, China \\ ***State Key Laboratory of Petrochemical Pollution Control and Treatment, Beijing 102206, P. R. China \\ $†$ Corresponding author: Chengtun Qu; xianquct@163.com
}

Nat. Env. \& Poll. Tech.

Website: www.neptjournal.com

Received: 21-08-2020

Revised: $00-00-2020$

Accepted: 01-11-2020

\section{Key Words:}

Waste aciding fluid

Catalytic oxidation

Flocculating settling

Treatment process

\begin{abstract}
The acidizing and fracturing waste fluid in a wellsite in northern Shaanxi was treated by catalytic oxidation and flocculation precipitation. It investigated the effect of different coagulants and their dosage and the wastewater $\mathrm{pH}$ on coagulation precipitation. As for chemical oxidation experiment, it investigated the effect of oxidant dosage and reaction time on its treatment effect. The results showed that when $30 \%$ hydrogen peroxide (volume percentage) was added at the dosage of $0.3 \%$ and oxidized for $50 \mathrm{~min}$, the $\mathrm{pH}$ was adjusted to 7.5 and $350 \mathrm{mg} / \mathrm{L}$ polyaluminum chloride (PAC) and $4 \mathrm{mg} / \mathrm{L}$ polyacrylamide were added (PAM); after processing the waste liquid, total iron, chemical oxygen demand (COD), chromaticity, and average corrosion rate were reduced from $252.75 \mathrm{mg} / \mathrm{L}, 3427.50 \mathrm{mg} / \mathrm{L}, 624.15^{\circ}$, and $0.1226 \mathrm{~mm} / \mathrm{a}$ to $0.12 \mathrm{mg} / \mathrm{L}, 275.18 \mathrm{mg} / \mathrm{L}, 125^{\circ}$ and $0.0217 \mathrm{~mm} / \mathrm{a}$, respectively; effective removal of iron and color, reduced COD, and controlled corrosion was achieved.
\end{abstract}

\section{INTRODUCTION}

In the process of shale gas exploitation, hydraulic fracturing technology is needed to increase the recovery rate (Barati \& Liang 2014, Mauter \& Alvarez 2014, Lester et al. 2013). Hydraulic fracturing is accomplished by injecting a large amount of fracturing fluid into the formation to improve reservoir permeability (Glaze \& Kang 1989). Combining acidizing and fracturing operations for oil and gas well transformation is an important method used for oil and gas field stimulation (Olsson et al. 2013, Davarpanah 2018). After the fracturing operation is completed, most of the fracturing fluid will be returned to the ground after breaking the rubber to form shale gas fracturing flowback fluid. A variety of additives are often added to the fracturing fluid to meet the requirements of sand carrying and drag reduction (Adham et al. 2018, Puspita 2015). At the same time, it will contact with oil and gas, water and rocks in the stratum during the fracturing process, resulting in many types of pollutants in the fracturing fluid. The viscosity is high and the treatment is difficult (Poyatos et al. 2010, Amr et al. 2013, Boczkaj et al. 2010, Bello et al. 2017). If it is not treated, it will cause environmental pollution. The development of shale gas fracturing flowback fluid treatment and reuse technology is of great significance for shale gas development and environmental protection (Reilly et al. 2015, You et al. 2019). Recently, advanced oxidation process (AOP) has been successfully used to treat industrial wastewaters that are non-biodegradable and toxic to microorganisms (Kim et al. 2004, Boczkaj \& Fernandes 2017, Li et al. 2018) Especially, Fenton oxidation has been applied for the decolorization of effluents from textile dyeing process and dye manufacturing process. Compared to other oxidation processes, such as $\mathrm{UV} / \mathrm{H}_{2} \mathrm{O}_{2}$ process, costs of Fenton oxidation are quite low (Dutta et al. 2001). Fenton oxidation has been lately used for different treatment processes because of its ease of operation, the simple system and the possibility to work in a wide range of temperatures (Solozhenko et al. 1995). At present, the main treatment method for fracturing waste liquid is oxidation viscosity reduction with coagulation and precipitation. The main treatment technology for acidification waste liquid is alkali neutralization with coagulation and precipitation (Makhathini et al. 2020, Mao 2018 et al). In recent years, research has focused on identifying highly efficient, widely applicable, and economical treatment technologies for acidizing and fracturing waste fluid.

Water quality characteristics of the acidizing and fracturing waste liquid from a wellsite in northern Shaanxi, was analyzed. According to the characteristics of fracturing wastewater, the suspended solids and colloidal in waste liquid 
were removed by coagulation sedimentation. Removal of iron and color, reduction of COD removal, and corrosion control were investigated using catalytic oxidation and flocculation precipitation (Zhang et al. 2020). Then the COD of wastewater was reduced by chemical oxidation treatment in order to achieve recycling standard of enterprise. The hydroxy radicals $(\cdot \mathrm{OH})$ produced in the process could oxidate the organic compounds in the wastewater so that the wastewater can meet the discharge standard (Szpyrkowicz et al. 2001, Arslan \& Balciolu 1999). This study aims to provide technical guidance for effective waste processing of acidizing and fracturing waste liquid through discussing experimental conditions. It investigated the effect of different coagulants and their dosage and the wastewater $\mathrm{pH}$ on coagulation precipitation. As for the chemical oxidation experiment, it investigated the effect of oxidant dosage and reaction time on its treatment effect.

\section{MATERIALS AND METHODS}

\section{Instrumentation and Reagents}

Instrumentation used in the study was the following: UV-Vis spectrophotometer (UV-2350, Shanghai Right Instrument Co., LTD.), electronic balance (CP214, Mr. Hauser Instrument Co., LTD.) and circulating water vacuum pump (SHZ-D (III), Gongyi City Instrument Co., LTD in China). Reagents used in the experiment were the following: hydrogen peroxide $(30 \%)$, concentrated sulfuric acid, congo red test paper, hydroxylamine hydrochloride, sodium hydroxide, polyaluminum chloride (PAC), polyacrylamide (PAM).

\section{Water Quality Characteristics Analysis Method}

The determination of $\mathrm{Fe}^{2+}, \mathrm{Fe}^{3+}$ plasma, and COD in waste liquid was performed in accordance with water and wastewater detection methods and an oil and gas field water analysis method (Ferrer \& Thurman 2015). Oil and suspended matter content were determined using a recommended index and an analysis method of water injection quality of a clastic reservoir (Oetjen \& Thomas 2016). Corrosion rates were determined using a water corrosion test method (Pier et al. 2018).

\section{Determination of Viscosity, Chromaticity and Light Transmittance}

(1) Viscosity: The passage time of distilled water and the passage time of water sample were determined using a Uhler viscometer, and water sample viscosity was calculated according to equation (1).

$$
\mu=\left(t_{2} \times r\right) / t_{1}
$$

$$
\begin{aligned}
t_{1} & =\text { time required for distilled water, } \mathrm{s} \\
\mathrm{t}_{2} & =\text { passage time required for water sample, } \mathrm{s} \\
\mathrm{r} & =\text { density of water sample } \mathrm{g} / \mathrm{cm}^{3} \\
\mathrm{~m} & =\text { viscosity of water sample, } \mathrm{mPa} \cdot \mathrm{s}
\end{aligned}
$$

(2) Chromaticity: The water sample absorbance was measured at $350 \mathrm{~nm}$. According to the chromaticity standard curve and due to the high chromaticity of the water sample, the measured value was calculated after making a 1:10 dilution.

(3) Light transmittance: The light transmittance of the water sample was measured at $680 \mathrm{~nm}$. Due to the low light transmittance of the water sample, the measured value was calculated after making a 1:10 dilution.

\section{Optimization Method for Catalytic Oxidation Agent System}

The $\mathrm{pH}$ was adjusted to 7.5 after a certain volume of hydrogen peroxide was added and oxidized for a certain time. PAC, an inorganic flocculant, and PAM, a coagulant, were added and allowed to stand for $30 \mathrm{~min}$. The light permeability of the clear liquid was based on optimal dosage of $\mathrm{H}_{2} \mathrm{O}_{2}$, the oxidant, oxidation time, flocculant dosage, and interval time.

\section{RESULTS AND DISCUSSION}

\section{Analysis of Water Quality Characteristics}

The water sample was taken from the acidizing and fracturing waste fluid of a well site in northern Shaanxi. Following the standards and methods mentioned in Section 1.2, the water quality characteristics of the waste liquid were analyzed. The results are shown in Table 1. The content of divalent iron was $218.25 \mathrm{mg} / \mathrm{L}$. The viscosity was relatively low at 1.11 $\mathrm{mPa} \cdot \mathrm{s}$. Oil content and suspended substance content were low, at $9.69 \mathrm{mg} / \mathrm{L}$ and $37.00 \mathrm{mg} / \mathrm{L}$, respectively. Chromaticity

Table 1: The characteristics of wastewater.

\begin{tabular}{|lll|}
\hline Serial number & Test items & Content \\
\hline 1 & $\mathrm{pH}$ & 3.5 \\
2 & $\mathrm{Fe}^{2+}\left(\mathrm{mg} \cdot \mathrm{L}^{-1}\right)$ & 218.25 \\
3 & $\mathrm{Fe}^{3+}\left(\mathrm{mg} \cdot \mathrm{L}^{-1}\right)$ & 34.50 \\
4 & Oil $\left(\mathrm{mg} \cdot \mathrm{L}^{-1}\right)$ & 9.69 \\
5 & Suspended solids $\left(\mathrm{mg} \cdot \mathrm{L}^{-1}\right)$ & 37 \\
6 & Chromaticity $\left(^{\circ}\right)$ & 624.15 \\
7 & Viscosity $(\mathrm{mPa} \cdot \mathrm{s})$ & 1.11 \\
8 & Light transmittance $(\%)$ & 25.82 \\
9 & COD $\left(\mathrm{mg} \cdot \mathrm{L}^{-1}\right)$ & 3427.50 \\
10 & Mean corrosion rate $(\mathrm{mm} / \mathrm{a})$ & 0.1226 \\
\hline
\end{tabular}


was high and reached $624.15^{\circ}$ in the case of $1: 10$ dilution. Light transmittance was low at only $25.82 \%$ in a $1: 10$ dilution, and COD was high at $3427.50 \mathrm{mg} / \mathrm{L}$. The average corrosion rate was high at $0.1226 \mathrm{~mm} / \mathrm{a}$, suggesting strong corrosion.

\section{Analysis of Catalytic Oxidation Process}

The concentration of $\mathrm{Fe}^{2+}$ in the acidizing and fracturing liquid concentration was high, up to $218.25 \mathrm{mg} / \mathrm{L}$, and the $\mathrm{pH}$ was 3.5. According to the principle of Fenton's reagent, a solution of $\mathrm{H}_{2} \mathrm{O}_{2}$ in an acidic environment ( $\mathrm{pH}$ is generally 3 to 4) (Tang et al. 2018), with $\mathrm{Fe}^{2+}$ as a catalyst can produce hydroxyl free radicals $(\cdot \mathrm{OH})$ and organic macromolecules, which reduces ion in the waste liquid. Bacteria and other pollutants have strong oxidation capabilities and can degrade macromolecular structures, and $\mathrm{Fe}^{3+}$ and $\mathrm{Fe}^{2+}$ can be converted to waste liquid. Stable gel breaking off can be achieved, which strengthens flocculation and bactericidal activities (Yoon et al. 2001, Watts et al. 2005). Therefore, the acidic environment and water quality characteristics of the waste liquid, such as high content of iron divalent, were utilized to conduct catalytic oxidation treatment of the acidified and fracturing waste liquid according to the method described in the section 1.4. As for chemical oxidation experiment, it investigated the effect of the oxidant dosage and reaction time on its treatment effect.

\section{Effect of $\mathrm{H}_{2} \mathrm{O}_{2}$ Addition on the Reaction}

The oxidant dosage $\left(\mathrm{H}_{2} \mathrm{O}_{2}\right)$ were optimized. The effects of oxidant dosage on COD removal rate and transmittance rate were investigated. The experimental results of $\mathrm{H}_{2} \mathrm{O}_{2}$ optimization amount are shown in Fig. 1 and Table 2 .

As shown in Fig. 1, when the dosage of $\mathrm{H}_{2} \mathrm{O}_{2}$ increases from $0.1 \%$ to $0.3 \%$, the COD removal rate of wastewater

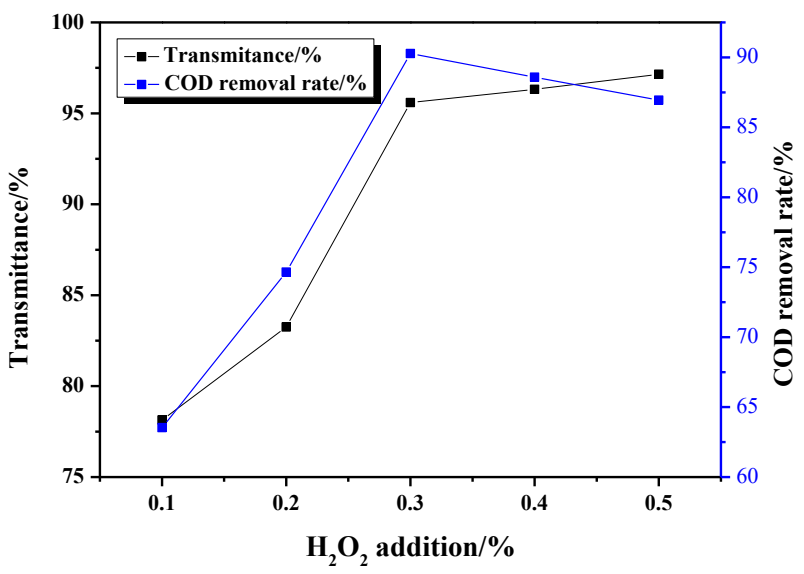

Fig. 1: $\mathrm{H}_{2} \mathrm{O}_{2}$ optimization amount. gradually increases in the proportion of the increase of the amount of $\mathrm{H}_{2} \mathrm{O}_{2}$. However, when the dosage of $\mathrm{H}_{2} \mathrm{O}_{2}$ increases from $0.3 \%$ to $0.5 \%$, the removal rate of COD in wastewater gradually decreases. When the dosage of $\mathrm{H}_{2} \mathrm{O}_{2}$ is $0.3 \%$, the COD removal rate reaches the maximum. When the concentration of $\mathrm{H}_{2} \mathrm{O}_{2}$ is low, the COD removal rate of wastewater increases with the increase of $\mathrm{H}_{2} \mathrm{O}_{2}$ concentration $\left(\mathrm{Fe}^{2+}+\mathrm{H}_{2} \mathrm{O}_{2} \rightarrow \mathrm{Fe}^{3+}+\cdot \mathrm{OH}+\mathrm{OH}^{-}\right)$. When the amount of $\mathrm{H}_{2} \mathrm{O}_{2}$ exceeds $0.3 \%$, the removal effect of $\mathrm{H}_{2} \mathrm{O}_{2}$ on $\cdot \mathrm{OH}$ increases with the increase of $\mathrm{H}_{2} \mathrm{O}_{2}$ added $\left(\mathrm{H}_{2} \mathrm{O}_{2}+\cdot \mathrm{OH} \rightarrow \mathrm{H}_{2} \mathrm{O}+\cdot \mathrm{OH}_{2}\right)$. Moreover, the high concentration of $\cdot \mathrm{OH}$ produced by the decomposition of high concentration of $\mathrm{H}_{2} \mathrm{O}_{2}$ will also oxidize $\mathrm{Fe}^{2+}$ to $\mathrm{Fe}^{3+}$, thereby reducing the utilization of $\cdot \mathrm{OH}$ and reducing the COD removal rate. It can be seen from Figure 1 that the transmittance of wastewater increases with the increase of $\mathrm{H}_{2} \mathrm{O}_{2}$ dosage. The flocculation and settlement phenomena are shown in Table 2.

\section{Effect of Oxidation Time on the Reaction}

The oxidation time was optimized. The effects of oxidation time on COD removal rate and transmittance rate was

Table 2: $\mathrm{H}_{2} \mathrm{O}_{2}$ optimization amount.

\begin{tabular}{|c|c|}
\hline $\mathrm{H}_{2} \mathrm{O}_{2}$ addition $/ \%$ & Flocculation and sedimentation \\
\hline 0.1 & $\begin{array}{l}\text { The floc was loose and less in quantity, and the } \\
\text { supernatant was turbid. }\end{array}$ \\
\hline 0.2 & $\begin{array}{l}\text { The floc was loose and less in quantity, and the } \\
\text { supernatant was turbid. }\end{array}$ \\
\hline 0.3 & $\begin{array}{l}\text { The floc volume is large and dense, and the } \\
\text { supernatant is clear }\end{array}$ \\
\hline 0.4 & $\begin{array}{l}\text { The floc volume was large and dense, and the } \\
\text { supernatant was clear and had air floatation. }\end{array}$ \\
\hline 0.5 & $\begin{array}{l}\text { The floc volume was large and dense, and the } \\
\text { supernatant was clear and had air floatation. }\end{array}$ \\
\hline
\end{tabular}

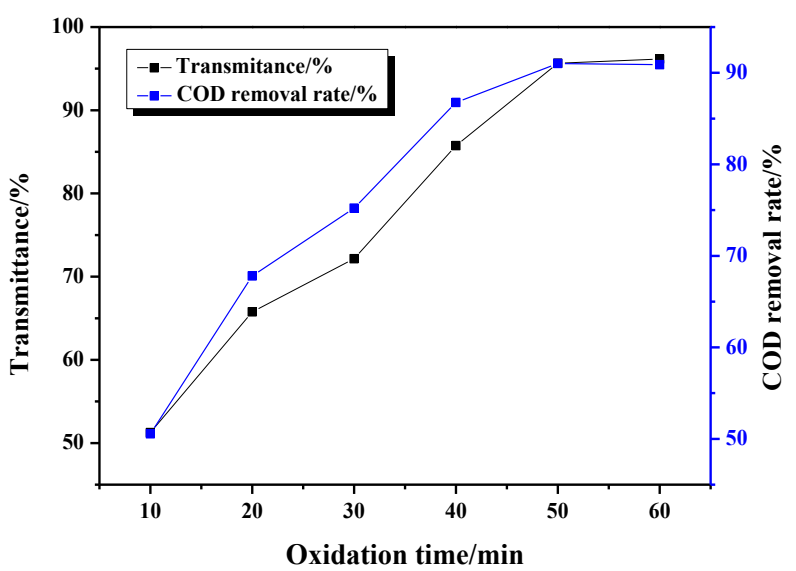

Fig. 2: Optimization of oxidation time. 
investigated. the experimental results of optimization of oxidation time are shown in Tables 3 and Fig. 2.

It can be seen from Fig. 2 that with the extension of time, the COD removal rate of wastewater increases gradually. The COD removal rate reached the highest in $50 \mathrm{~min}$. With the extension of time, the COD removal rate tends to be stable, and the transmittance of wastewater increases with the increase of $\mathrm{H}_{2} \mathrm{O}_{2}$ dosage. $\mathrm{H}_{2} \mathrm{O}_{2}$ produced an increase in $\cdot \mathrm{OH}$ in the $\mathrm{Fe}^{2+}$ catalyzed waste liquid (Oetjen \& Thomas 2016). In the waste liquid, organic macromolecular chain structures play an important role in oxidative damage, which destroys the stability of the waste liquor colloid system (Gordalla et al. 2013), and in turn, flocculation settlement is reinforced. Therefore, from the oxidation-flocculation effect, it can be concluded that the addition of $\mathrm{H}_{2} \mathrm{O}_{2}$ in the catalytic oxidation-flocculation experiment of the waste aciding fluid is optimal at $0.3 \%$ and when the oxidation time is $50 \mathrm{~min}$. The flocculation and settlement phenomena are shown in Table 3.

\section{Analysis of Flocculation and Precipitation Process}

Waste aciding fluid will produce a strong corroding and alkaline environment required by the flocculant. At the same time, the $\mathrm{Fe}^{2+}$ remaining in the waste liquid after catalytic oxidation treatment will be converted into $\mathrm{Fe}^{3+}$. In an alkaline environment, a $\mathrm{Fe}(. \mathrm{OH})_{3}$ precipitate will be formed, which has strong adsorption, coagulation, and flocculation characteristics (Costa et al. 2017, Kreipl \& Kreipl 2017, Wisen et al. 2019). Therefore, neutralization of the alkaline environment first occurs during flocculation precipitation, followed by flocculation precipitation treatment. According to the method described in section 1.4, after catalytic oxidation the waste liquid was flocculated and precipitated. It investigated the effect of different coagulants and their dosage and the wastewater $\mathrm{pH}$ on coagulation precipitation.

\section{The Effects of the Wastewater $\mathrm{pH}$ on Coagulation}

The effects of $\mathrm{pH}$ on COD removal rate and transmittance rate were investigated. The experimental results of $\mathrm{pH}$

Table 3: Optimization of oxidation time.

\begin{tabular}{|ll|}
\hline Oxidation time/min & Flocculation and sedimentation \\
\hline 10 & Loose flocs, less amount, slow settlement \\
20 & Loose flocs, less amount, slow settlement \\
30 & Loose flocs, less amount, slow settlement \\
40 & Loose flocs, less amount, slow settlement \\
50 & The floc is compact, large in quantity and quick \\
& in settling \\
60 & The floc is compact, large in quantity and quick \\
& in settling \\
\hline
\end{tabular}

optimization in flocculation and precipitation are shown in Fig. 3.

It can be seen from Fig. 3 that the COD removal rate of wastewater increases with the increase of $\mathrm{pH}$. With the increase of $\mathrm{pH}, \mathrm{COD}$ removal rate tends to be stable. At the same time, with the increase of $\mathrm{pH}$, the transmittance of wastewater increases gradually, and tends to be stable with the increase of $\mathrm{pH}$. However, considering the reagent cost and reason of sludge discharge, and alkalinity neutralization at the optimal $\mathrm{pH}$ of 7.5 , the transmittance can reach more than $95 \%$ after processing wastewater.

\section{The Effects of Different Flocculants and Their Dosage on Coagulation}

The effects of different flocculants and their dosage on COD removal rate and transmittance rate were investigated.

The experimental results of optimization of flocculant types are shown in Table 4.

It can be seen from Table 4 that the light transmittance can reach $90 \%$ when PAC flocculant is used, but it is lower when PFC flocculant is used. Therefore, PAC was used as the best flocculant.

The experimental results of optimization of flocculant PAC addition are shown in Fig. 4.

From Fig. 4 it can be infrerred that the COD removal rate increases with the increase of PAC dosage, when PAC dosage is $350 \mathrm{mg} / \mathrm{L}$, the COD removal efficiency reaches at its best,

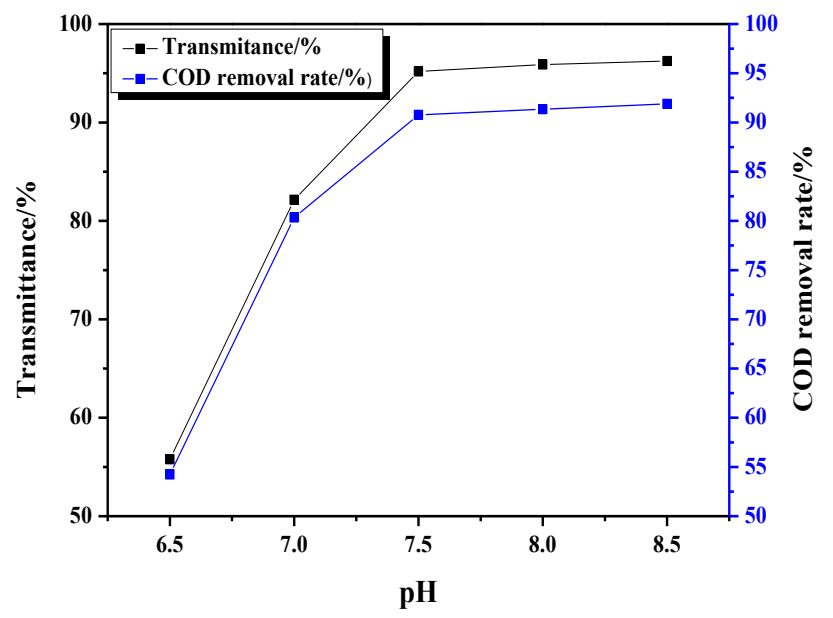

Fig. 3: pH optimization in flocculation and precipitation.

Table 4: Optimization of flocculant types.

\begin{tabular}{|lll|}
\hline Types of flocculants & PAC & PFS \\
\hline Transmittance (\%) & 97.3 & 45.6 \\
\hline
\end{tabular}


and the COD removal rate is $91.95 \%$. When PAC dosage continued to increase, the COD removal rate decreased slightly. From Fig. 4 it can be inferred that the transmittance of wastewater increases with the increase of PAC dosage.

\section{The Effects of Different Coagulants and Their Dosage on Coagulation}

The experimental results of preferred coagulant types are given in Table 5, which show that when a coagulant has an ion degree of $12 \%$ and a molecular weight of $8 \times 10^{6}$ and the Types of PAM is $7^{\#}$, the water transmittance after treatment can reach more than $98.8 \%$.

The experimental results of Optimization of coagulant $7^{\#}$ addition are shown in Fig. 5. The COD removal rate increases with the increase of the PAC dosage. When the dosage of $\mathrm{PAC}$ is $3 \mathrm{mg} / \mathrm{L}$, the COD removal effect reaches at its best, and the COD removal rate is $91.84 \%$; when the dosage of PAC continues to increase, the COD removal rate decreases slightly. Fig. 5 shows that the transmittance of wastewater increases with the increase of coagulant $7^{\#}$ dosage, and the coagulant $7^{\#}$ is dosed at $4 \mathrm{mg} / \mathrm{L}$, the water transmittance after treatment can reach more than $99 \%$.

As shown by Fig. 3, as the $\mathrm{pH}$ increased, and flocculation improved. With an increase in alkalinity, ferric iron ion and hydroxyl ions form iron hydroxide precipitation, resulting in a flocculation precipitation strengthening effect (Ge et al. 2015). However, considering the reagent cost and reason of sludge discharge, and alkalinity neutralization at the optimal $\mathrm{pH}$ of 7.5, the light transmittance can reach more than 95\% after processing wastewater. The flocculation and precipitation conditions were optimized successively. As can be seen from Table 4 and Fig. 4, PAC was selected as the inorganic flocculant, and the effect was improved when the PAC dosage was $350 \mathrm{mg} / \mathrm{L}$. It is shown in Table 5 and Fig. 5 that when a coagulant has an ion degree of $12 \%$, and a molecular weight of $8 \times 10^{6}$, and the PAM is dosed at $4 \mathrm{mg} / \mathrm{L}$, the water transmittance after treatment can reach more than $99 \%$.

The most effective catalytic oxidation and flocculation precipitation process for treating shale gas fracturing and acidizing liquid wastewater is indicated by the water quality indicators shown in Table 6. Results are as follows: $\mathrm{pH}$ increased to $7.5, \mathrm{Fe}^{2+}$ was reduced to $0.10 \mathrm{mg} / \mathrm{L}$, COD was reduced to $275.18 \mathrm{mg} / \mathrm{L}$, chromaticity was reduced to $125^{\circ}$, and the average corrosion rate decreased to $0.0217 \mathrm{~mm} / \mathrm{a}$.

\section{CATALYTIC OXIDATION WITH FLOCCULATION AND PRECIPITATION TREATMENT PROCESS}

Based on the experiment results, the process of catalytic oxidation with flocculation and precipitation was proposed to treat waste liquid. The process flow is shown in Fig. 6.

Table 5: Preferred coagulant types.

\begin{tabular}{|lllllllll|}
\hline Types of PAM & 1 & 2 & 3 & 4 & 5 & 6 & 7 \\
\hline $\begin{array}{l}\text { Ion/\% } \\
\begin{array}{l}\text { Molecular weight/ } \\
\text { (ten thousand) }\end{array}\end{array}$ & 20 & 30 & 40 & 50 & 60 & Non-ionic & 12 & 800 \\
\begin{tabular}{l} 
Transmittance/\% \\
\hline
\end{tabular} & 800 & 800 & 1200 & 800 & 800 & Anion & 98.3 & 98.8 \\
\hline
\end{tabular}

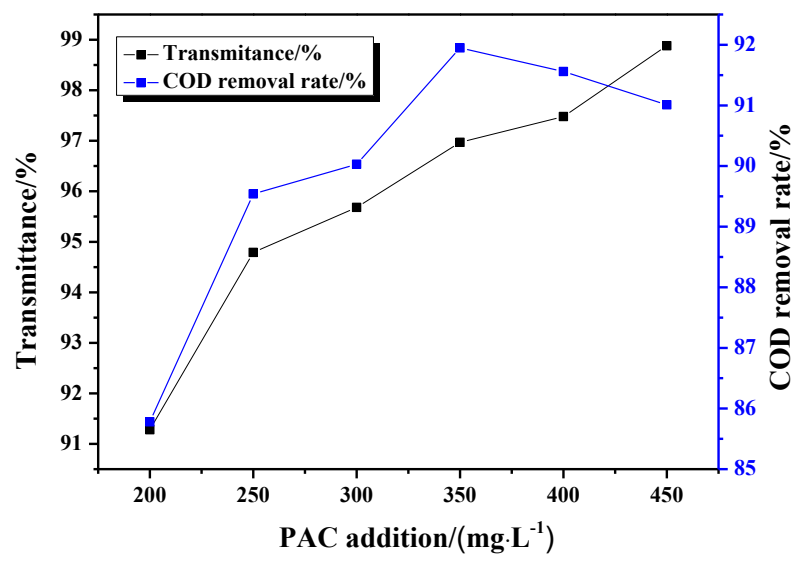

Fig. 4: Optimization of flocculant PAC addition.

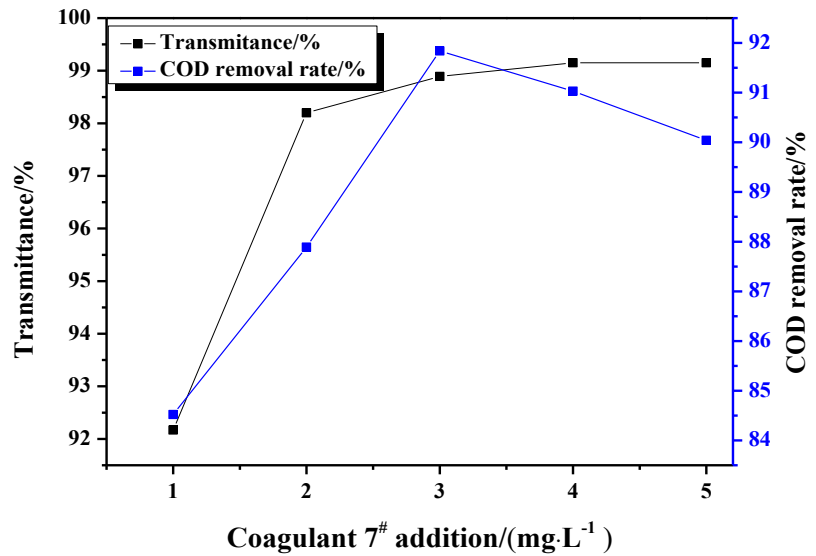

Fig. 5: Optimization of coagulant $7^{\#}$ addition. 
Table 6: Water quality analysis after treatment.

\begin{tabular}{|lll|}
\hline S. No. & Test items & Content \\
\hline 1 & $\mathrm{pH}$ & 3.5 \\
2 & $\mathrm{Fe}^{2+}\left(\mathrm{mg} \cdot \mathrm{L}^{-1}\right)$ & 0.10 \\
3 & $\mathrm{Fe}^{3+}\left(\mathrm{mg} \cdot \mathrm{L}^{-1}\right)$ & 0.02 \\
4 & Oil $\left(\mathrm{mg} \cdot \mathrm{L}^{-1}\right)$ & 2.98 \\
5 & Suspended solids $\left(\mathrm{mg} \cdot \mathrm{L}^{-1}\right)$ & 8 \\
6 & Chromaticity $\left(^{\circ}\right)$ & 125 \\
7 & Viscosity $(\mathrm{mPa} \cdot \mathrm{s})$ & 0.97 \\
8 & Light transmittance $(\%)$ & 99.15 \\
9 & COD $\left(\mathrm{mg} \cdot \mathrm{L}^{-1}\right)$ & 275.18 \\
10 & Mean corrosion rate $(\mathrm{mm} / \mathrm{a})$ & 0.0217 \\
\hline
\end{tabular}

The treatment process can be divided into three stages. The first stage is catalytic oxidation, which mainly includes Fenton's reagent condition optimization ( $\mathrm{pH}$, catalyst, oxidant) and oxidation time optimization. The second stage is flocculation precipitation, including alkali neutralization, flocculant optimization and, coagulant optimization. The third stage is feasibility analysis and treatment of water reuse mixture, including a feasibility analysis of a water reuse mixture after treatment and removal of related heavy metal ions.

\section{CONCLUSION}

(1) Acidified fracturing waste liquid is characterized by low $\mathrm{pH}$, high chromaticity, high iron content, high COD, and low light transmittance. Catalytic oxidation with flocculation and precipitation is the process selected for treatment.

(2) The water transmission rate increased from $25.82 \%$ to $99.15 \%$ and the average corrosion rate decreased from
$0.1226 \mathrm{~mm} / \mathrm{a}$ to $0.0217 \mathrm{~mm} / \mathrm{a}$ after catalytic oxidation with flocculation and precipitation treatment. The dosage of $\mathrm{H}_{2} \mathrm{O}_{2}$ was $0.3 \%$ in the catalytic oxidation process, and $\mathrm{pH}$ was 7.5 during flocculation and precipitation. The PAC concentration dosage was $350 \mathrm{mg} / \mathrm{L}$, and the dosage of PAM with ion degree of $12 \%$ and molecular weight of $8 \times 10^{6}$ was $4 \mathrm{mg} / \mathrm{L}$.

\section{ACKNOWLEDGMENTS}

This work was supported by the Open Project Program of State Key Laboratory of Petroleum Pollution Control, and Shaanxi Youth Science and technology new star project (2017KJXX-49); and Scientific Research Program Funded by Shaanxi Provincial Education Department (Program No.18JS088), and Natural Science Basic Research Plan in Shaanxi Province of China (Program 2019JM-506).

\section{REFERENCES}

Adham, S., Hussain, A., Minier-Matar, J., Janson, A. and Sharma, R. 2018. Membrane applications and opportunities for water management in the oil \& gas industry. Desalination, 2-17.

Amr, S. S. A., Aziz, H. A. and Adlan, M. N. 2013. Optimization of stabilized leachate treatment using ozone/persulfate in the advanced oxidation process. Waste Management, 33(6): 1434-1441.

Arslan, I. and Balciolu, I. A. 1999. Degradation of commercial reactive dyestuffs by heterogenous and homogenous advanced oxidation processes: a comparative study. Dyes \& Pigments, 43(2): 95-108.

Barati, R. and Liang, J. T. 2014. A review of fracturing fluid systems used for hydraulic fracturing of oil and gas wells. J. Appl.Polym. Sci., 131(16): 318-323.

Boczkaj, G., Kami ski, Marian and Przyjazny, A. 2010. Process control and investigation of oxidation kinetics of postoxidative effluents using gas chromatography with pulsed flame photometric detection (gc-pfpd). Ind. Eng. Chem. Res., 49(24): 12654-12662.

Bello, M. M. and Raman, A. A. A. 2017. Trend and current practices of palm oil mill effluent polishing: application of advanced oxidation processes and their future perspectives. J. Environ. Manag., 198(pt.1): 170-182.

Boczkaj, G. and Fernandes, André. 2017. Wastewater treatment by means of
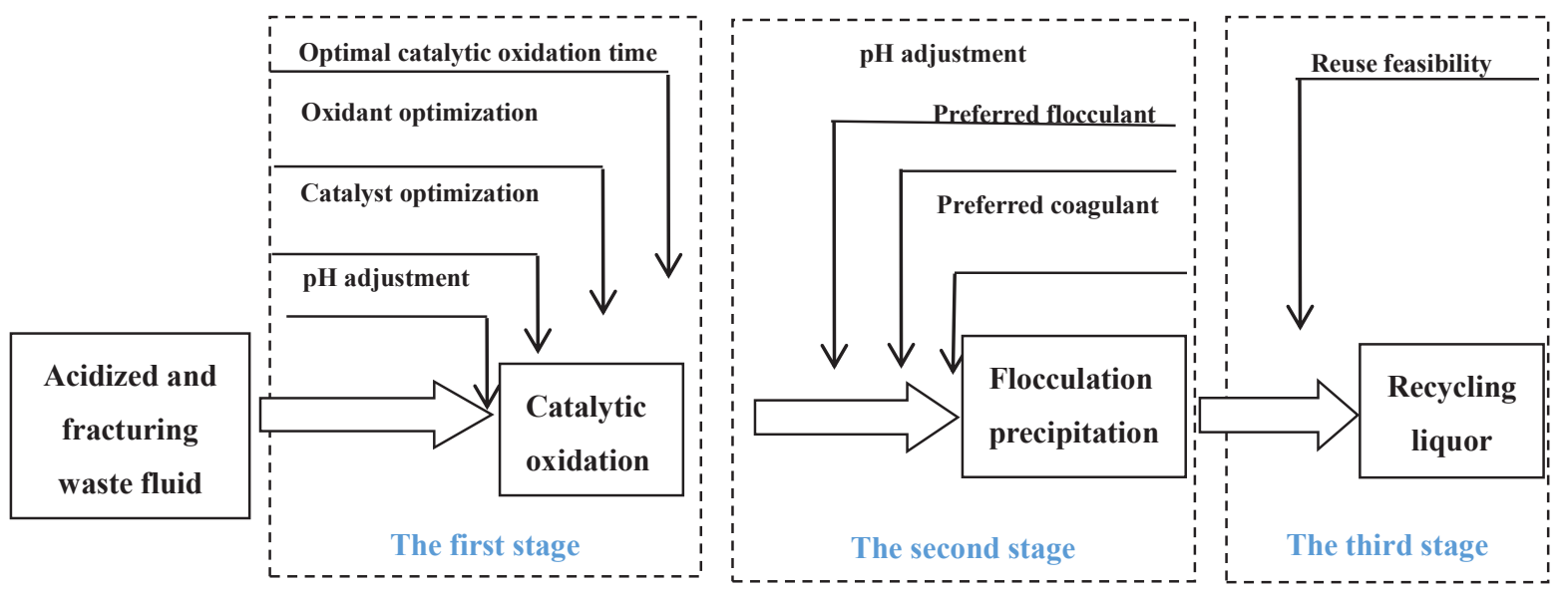

Fig. 6: Catalytic oxidation with flocculation precipitation treatment process. 
advanced oxidation processes at basic ph conditions: a review. Chem. Eng. J., 320: 608-633.

Costa, D., Jesus, J., Branco, D., Danko, A. and Fiúza, António. 2017. Extensive review of shale gas environmental impacts from scientific literature (2010-2015). Environ. Sci. \& Pollut. Res., 24(17): 1-16.

Davarpanah A. 2018. Feasible analysis of reusing flowback produced water in the operational performances of oil reservoirs. Environ.Sci.Pollut. Res. Int., 25(35):35387-35395.

Dutta, K., Mukhopadhyay, S., Bhattacharjee, S. and Chaudhuri, B. 2001. Chemical oxidation of methylene blue using a fenton-like reaction. J. Hazard. Mater., 84(1): 57-71.

Ferrer, I. and Thurman, E.M. 2015. Analysis of hydraulic fracturing additives by lc/q-tof-ms. Anal. Bioanal. Chem., 407(21): 6417-6428.

Glaze, W. H. and Kang, J. W. 1989. Advanced oxidation processes. description of a kinetic model for the oxidation of hazardous materials in aqueous media with ozone and hydrogen peroxide in a semibatch reactor. Ind. Eng. Chem. Res., 28(11):1573-80

Gordalla, B. C., Ewers, U. and Frimmel, F. H. 2013. Hydraulic fracturing: a toxicological threat for groundwater and drinking-water? Environ. earth Sci., 70(8): 3875-3893.

Ge, H., Yang, L., Shen, Y., Ren, K., Meng, F., Ji, W. and Wu, S. 2015. Experimental investigation of shale imbibition capacity and the factors influencing loss of hydraulic fracturing fluids. Pet. Sci., 12(4): 636-650.

Kim, T. H., Park, C., Yang, J. and Kim, S. 2004. Comparison of disperse and reactive dye removals by chemical coagulation and fenton oxidation. $\mathrm{J}$. Hazard. Mater., 112(1-2): 95-103.

Kreipl, M. P. and Kreipl, A. T. 2017. Hydraulic fracturing fluids and their environmental impact: then, today, and tomorrow. Environ. Earth Sci., 76(4): 160.

Lester, Y., Yacob, T., Morrissey, I. and Linden, K. G. 2013. Can we treat hydraulic fracturing flowback with a conventional biological process? the case of guar gum. Environ. technol. lett., 1(1): 133-136.

Li, L., Yang, Z., Yu, Z., Hong, T. and Tian, Y. 2018. Study on the Oxidation Process of As (III) in Acidic Wastewater Containing Arsenic by Electrolysis and Ultrasonic Coupling. Nature Environ. Pollut. Technol., 17(4): 1419-1424.

Mauter, M. S., Alvarez, P. J. J., Burton, A., Cafaro, D. C., Chen, W. and Gregory, K. B. et al. 2014. Regional variation in water-related impacts of shale gas development and implications for emerging international plays. Environ. Sci. Technol., 48(15): 8298-306.

Makhathini, T. P., Mulopo, J. and Bakare, B. F. 2020. Possibilities for acid mine drainage co-treatment with other waste streams: a review. Mine Water Environ., 39(1): 1-14.

Mao J, Zhang C, Yang X, Zhang Z. 2018. Investigation on problems of wastewater from hydraulic fracturing and their solutions. Water, Air, \& Soil Pollut.
Olsson, O., Weichgrebe, D. and Rosenwinkel, K. H. 2013. Hydraulic fracturing wastewater in germany: composition, treatment, concerns. Environ. Earth Sci., 70(8): 3895-3906.

Oetjen, K. and Thomas, L. 2016. Volatile and semi-volatile organic compound patterns in flowback waters from fracturing sites within the marcellus shale. Environ. Earth Sci., 75(12): 1043.

Oetjen, K. and Thomas, L. 2016. Volatile and semi-volatile organic compound patterns in flowback waters from fracturing sites within the marcellus shale. Environ. Earth Sci., 75(12): 1043.

Puspita, P., Roddick, F. and Porter, N. 2015. Efficiency of sequential ozone and uv-based treatments for the treatment of secondary effluent. Chem. Eng. J., 268: 337-347.

Poyatos, J. M., Munio, M. M., Almecija, M. C., Torres, J. C., Hontoria, E. and Osorio, F. 2010. Advanced oxidation processes for wastewater treatment: state of the art. Water Air Soil Pollut, 205(1-4), 187-204.

Pier, R., Gaspar-Vargas, B., Romero, A. and Nilsson, M. 2018. Comparative study using ion exchange resins to separate and reduce norm from oil and gas flowback wastewater. J. Radioanal. Nucl. Chem., 318(1): 497-503.

Reilly, D., Singer, D., Jefferson, A. and Eckstein, Y. 2015. Identification of local groundwater pollution in northeastern pennsylvania: marcellus flowback or not?. Environ. Earth Sci., 73(12): 8097-8109.

Solozhenko, E. G., Soboleva, N. M. and Goncharuk, V. V. 1995. Decolourization of azodye solutions by fenton's oxidation. Water Res., 29(9): 2206-2210.

Szpyrkowicz, L., Juzzolino, C. and Kaul, S. N. 2001. A comparative study on oxidation of disperse dyes by electrochemical process, ozone, hypochlorite and fenton reagent. Water Res., 35(9): 2129-2136.

Tang, Y., Ren, H., Yang, P., Li, H., Zhang, J. and Qu, C. et al. 2018. Treatment of fracturing fluid waste by fenton reaction using transition metal complexes catalyzes oxidation of hydroxypropyl guar gum at high ph. Environ. Chem. Lett., 17(1):559-64.

Watts, R. J., Sarasa, J., Loge, F. J. and Teel, A. L. 2005. Oxidative and reductive pathways in manganese-catalyzed fenton's reactions. J. Environ. Eng., 131(1): 158-164.

Wisen, J., Chesnaux, R., Wendling, G. and Werring, J. 2019. Water footprint of hydraulic fracturing in Northeastern British Columbia, Canada. Environ. Earth Sci., 78(24): 1-13.

You, L., Zhou, Y., Kang, Y., Yang, B., Cui, Z. and Cheng, Q. 2019. Fracturing fluid retention in shale gas reservoirs:mechanisms and functions. Arab. J. Geosci., 12(24): 1-17.

Yoon, J., Lee, Y. and Kim, S. 2001. Investigation of the reaction pathway of oh radicals produced by fenton oxidation in the conditions of wastewater treatment. Water Sci.Technol., 44(5), 15-21.

Zhang, B., Li, B., Zhang, D. and Li, J. 2020. Experimental research on permeability variation from the process of hydraulic fracturing of high-rank coal. Environ. Earth Sci., 79(1). 